\title{
O ANALIZĂ DISCURSIVĂ ASUPRA CELOR DOUĂ DIATE ALE MARIEI CANTEMIR ŞI A UNUI MODEL TESTAMENTAR INEDIT DE LA SFÂRȘITUL SECOLULUI AL XVIII-LEA
}

\section{DANIAR MUTALÂP}

\section{Universitatea din București}

Abstract: The present paper endeavours to offer a brief analysis of two wills written by the princess Maria Cantemir (1700-1757) during 1725 and 1757. Using discoursive concepts such as "scene of enunciation”, "discursive scenes" and "discursive ethos", followed by stylistics devices, our attempt aimed to capture the process of (re)constructing the self. Thus, comparing the two wills with an unedited testamentary letter sample (Romanian manuscript no. 2120 from Romanian Academy Library Bucharest) and to the process of writing and rewriting, our approach delineates how in articulo mortis Maria Cantemir (re)presents herself as „sister princess Maria Cantemirova”.

Keywords: testamentary letter, wills, Maria Cantemir, scene of enunciation

Discursul testamentar a reprezentat, în ultimele decenii, obiectul de studiu al lingviștilor, filologilor, istoricilor și tanatologilor români, de la Al. Mareș ${ }^{1}$, Gh. Chivu², Gabriela Stoica ${ }^{3}$, până la Ștefan Lemny ${ }^{4}$,

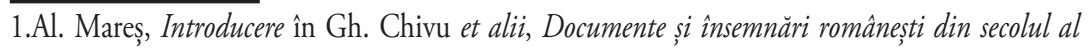
XVI-lea, București, Editura Academiei Române, 1979.

2. Gh. Chivu, Limba română de la primele texte până la sfârșitul veacului al XVIII-lea. Variantele stilistice, București, Editura Univers Enciclopedic, 2000.

3. Gabriela Stoica, Mihaela Constantinescu, Oana Uță Bărbulescu, Observații asupra dispozițiilor testamentare din secolul al XVII-lea, în Gabriela Pană Dindelegan (coord.), Limba română: dinamica limbii române, dinamica interpretării, București, Editura Universității din București, 2008.

4. Ștefan Lemny, Sensibilitatea și istorie în secolul XVIII românesc, ed. a II-a, Iași, Polirom, 2017. 
Violeta Barbu ${ }^{5}$, Nicolae Mihai ${ }^{6}$, Dan Horia Mazilu ${ }^{7}$, Cristina Bogdan ${ }^{8}$, Andreea Iancu ${ }^{9}$ ș.a., aceștia concentrându-se în mare măsură pe dispozițiile testamentare redactate între secolele XVI-XVII, când, în ciuda schematismului textual și în lipsa unui model oficial, aceste documente reliefau în special perspectiva subiectivă a testatorului ${ }^{10}$. Cu toate acestea, „scrierile tanatologice” din veacul următor ridică probleme interesante în materie de discurs literar prin raportarea lor atât la modelele tipărite cât și la cele ce au circulat în manuscrise în acea epocă.

În anul 1714 mitropolitul Antim Ivireanul tipărește la Târgoviște Capetele de poruncă către preoți, care conțin, alături de 8 reguli de întocmire a diatelor, un formular cunoscut drept primul model de testament din cultura românească veche ${ }^{11}$. Dintre aceste reglementări amintim condiția ca diata „să se făcă cu frica lui Dumnezeu”, „când sînt mințile omului întregi”, fără vreo vrajbă care să ducă la dezmoșteniri, întrucât, subliniază mitropolitul, „afurisaniile ce adaog pentru că sînt făr’ de cale vor cădea asupra lor" ${ }^{\prime 2}$. Acest izvod testamentar se găsește în șase copii manuscrise realizate între sfârșitul veacului al XVIII-lea și începutul celui de al XIXlea, fiind conservate la Biblioteca Academiei Române sub cotele 2158, 3275, 4765, 5579, 3774 și 3404². În Catalogul realizat de Gabriel Ștrempel aceste modele testamentare sunt intitulate, cu mici variații,

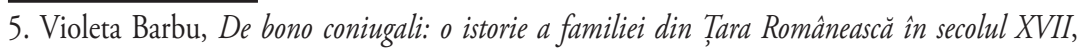
București, Meridiane, 2003.

6. Nicolae Mihai, Ultimul gest. Atitudini și reprezentări faţă de moarte in sursele testamentare din Oltenia (1700-1860) în Radu Mârza,Laura Stanciu (coord.), Cum scriem istoria? Apelul la ştiinţe şi dezvoltările metodologice contemporane, Alba -Iulia, Ed. Aeternitas, 2003.

7. Dan Horia Mazilu, Văduvele sau despre istorie la feminin, Iași, Polirom, 2008.

8. Cristina Dobre-Bogdan, Imago mortis în cultura românească veche (secolele XVII-XIX), București, Editura Universității din București, 2002.

9. Andreea-Roxana Iancu, Iertarea în actul de ultimă voință: între discurs și practică socială (Țara Românească, jumătatea secolului al XVIII-lea - începutul secolului al XIX-lea) în Constanța Vintilă-Ghițulescu și Mária Pakucs Willcocks (coord.), Spectacolul public între tradiție și modernitate: sărbători, ceremonialuri, pelerinaje și suplicii, București, Institutul Cultural Român, 2007, p. 265-300.

10. Gabriela Stoica, op. cit., p. 745.

11. BRV, vol. I, p. 492-493.

12. Antim Ivireanul, Opere, ed. de Gabriel Ștrempel, București, Minerva, 1972, p. 391.

13. Vezi Gabriel Ștrempel, Catalogul manuscriselor românești, vol. 1-4, București, Editura Științifică și Enciclopedică, 1978, 1983, 1987, 1992. 
Cum să face diiata sau Formular de diată (numai în cazul ultimelor două intrări fiind menționată asemănarea cu modelul antimian). Interesant este faptul că sub o denumire identică (Cum să scrie diiată la ceasul morții) este descris și un text din ms. 2120, deși acesta este unul cu totul diferit față de izvodul testamentar legiferat de Antim Ivireanul.

Manuscrisul românesc BAR 2120 a fost copiat la 1787 de dascălul Vasile din Cernat (Transilvania). Acest miscelaneu, preponderent hagiografic, conține Minunile Maicii Domnului, precum și vieți de sfinți ca cea a nebunului întru Hristos, Alexie, Omul lui Dumnezeu, Macarie Râmleanul sau Minunile sfântului Dimitrie, remarcându-se, astfel, faptul că principiul de selecție al compilatorului ${ }^{14}$ a fost dozajul de mirabil, respectiv miraculos medieval ${ }^{15}$. Între filele $217^{\mathrm{v}}$ și $218^{\mathrm{r}}$ se găsește textul intitulat Cum să scriie diiată la ceasul morții, un formular testamentar inedit care se diferențiază de izvodul tipărit la 1714 atât prin structură, cât și prin mărcile afective inerente conținutului. În acest sens, dacă preambulul din tipăritură rezumă incognoscibilitatea morții (,iaste nevăzută și însăși îngerilor necunoscută”), cel din manuscris este mult mai amplu, fiind concentrat pe păcatul primordial („şarpele cel rău și amăgitor”) prin care însăşi moartea devine moștenirea omului: „s-au dat și s-au hotărâ< $<>$ această moarte la tot neamul omenesc ca o moștenire și nu iaste cu putință ca să scape de dânsa niminea”. O diferență importantă constă în construcția și indicele afectiv al imprecației de la sfârșitul celor două formulare. În cazul izvodului tipărit blestemul este unul tipizat și face trimitere la Judecata de Apoi, în timp ce formula proferată din modelul manuscris prezintă o construcție mult mai complexă. Având o valoare profilactică, aceasta este anticipată de o presecvență în care se disting toți virtualii executori neloiali („,cine din rudeniile meale sau din străini”) şi în care este accentuată importanța clauzei date de testator, fapt vizibil prin utilizarea emfatică a pronumelui eu („,ce am așezat eu întâi”). Propriu-zis, blestemul de față se bazează pe paralelism și enumerarea unor elemente lexicalizate, efectul fiind amplificat de adverbul „aşijderea” folosit alături de juxtapunere și de copulativul anaforic „și”. În prima parte a imprecației, se remarcă invocarea instanțelor divine („Sfânta Troiță”, „toți sfinții părinți”) și implicarea lor directă în actul punitiv, desfăşurat la Judecata de Apoi,

14. Roland Barthes, Romanul scriiturii, antologie și trad. de Adriana Babeți și Delia Șepețean Vasiliu, București, Editura Univers, 1987, p. 155-156.

15. Jacques Le Goff, Imaginarul medieval, trad. de Marina Rădulescu, București, Meridiane, 1991. 
pandantul acestei părți fiind structura aflată în contextul imediat („partea lui să fie cu Viliar”) și cea finală („soarta lui să fie cu Iuda”), în care se face referire la personaje stigmatizate în creștinism (tabuul lingvistic „Viliar” și Iuda trădătorul). În centrul blestemului se află o acumulare de termeni tip poena spiritualis ce impun pedepse fizice: "gemând”, „tremurând”, „căloșaște”, „cu suspin să să îmbăloiască”, „pornirea iuților doriri”.

Analiza acestor documente in articulo mortis nu se poate reduce la compararea unor formulare, ci necesită o atenție sporită la felul în care exemple de testamente devin un „loc de întâlnire între inovația individuală și presiunea tradiției colective”"16. Astfel, aceste „pașapoarte spre cer” ${ }^{17}$, în care expierea și mântuirea depind de conjugarea bunurilor pământești cu cele cerești, pot fi privite ca discursuri literare ce se articulează în funcție de anumite „constrângeri” determinate de scena de enunțare („situația de comunicare” fragmentată în scena generică, înglobantă și scenografia).

În acest sens, din punct de vedere al scenei generice ${ }^{18}$, se remarcă faptul că redactarea dispozițiilor testamentare este condiționată și codificată social. Dacă în Evul Mediu Apusean întocmirea diatelor necesita prezența unui notar și a unui confesor, în cazul culturii românești vechi, preotul îndeplinea ambele funcții ${ }^{19}$. Pe lângă acesta, era necesară prezența a 7, 5 sau 3 martori, voci tăcute, care se manifestau abia la sfârșitul ceremonialului, atunci când semnau alături de preot testamentul întocmit. De remarcat este fapul că aceste prezențe schimbă dinamica relației emițător - text - receptor. Autorul nu mai este privit drept semnătură $\breve{b}^{20}$, ci drept vocea testatorului a cărui discurs este încorporat textual prin intermediul copistului. În plus, falia dintre locutorul - L (enunțătorul, în interiorul discursului) și locutorul - $\lambda$ („locutorul ca ființă ce aparține lumii”) ${ }^{21}$ este adâncită și redimensionată de faptul că inscriptorul nu

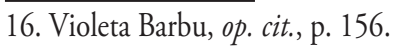

17. Jacques Le Goff, Civilizația Occidentului Medieval, trad. de Maria Holban, București, Editura Științifică, 1970, p. 262..

18. „Condițiile de enunțare corespunzătoare fiecărui gen” (orizontul de așteptare al lectorului și anticipările autorului) (Dominique Maingueneau, Discursul literar: paratopie și scenă de enunțare, trad. de Nicoleta Loredana Moroșan, Iași, Institutul European, 2007, p. 223).

19. Constanța Vintilă-Ghițulescu, În șalvari și cu ișlic: biserică, sexualitate, căsătorie și divorț în Țara Românească a secolului al XVIII-lea, București, Humanitas, 2011, p. 35-36.

20. Vezi Carmen Mușat, Frumoasa necunoscută : literatura și paradoxurile teoriei, Iași, Polirom, 2017, p. 127-131.

21. Dominique Maingueneau, op. cit., p. 237. 
corespunde cu a doua ipostază a locutorului, ethos-ul construindu-se în discurs la interstițiul dintre voce, grafie și mărturie. În această linie, testamentul poate fi privit ca un discurs asumat de un $e u$ care se justifică în faţa societății. Textul, cu valență de ego-document ${ }^{22}$, are valoarea unei confesiuni justificative ${ }^{23}$, o spovadă publică, una dintre formele extreme şi primordiale ale penitenței ${ }^{24}$. La anipodul acestei perspective, „epilogul pregătirii pentru moarte" este totodată un discurs personal, intim, în care eul se reconstruiește identitar, se înfruntă cu acea "frică teologică" 25 determinată de eshatologia personală, își gestionează bunurile - garant al memoriei familiale și liturgice - și, nu în ultimul rând, se confruntă cu și îmblânzește acea „moartea sălbatică” (mors repentina et improvisa) ${ }^{26}$.

Din perspectiva scenei inglobante ${ }^{27}$ se diferențiază patru tipuri de tesamente: donatio (bunuri lăsate bisericii), commendatio (gestionarea bunurilor între soți), distributiv (viza dezmoșteniri), nuncupatio (favoriza descendenții ${ }^{28}$. În plus, privit „din interior”, discursul testamentar respectă un tipar stilistic structurat pe trei părți: protocolul inițial, contextul și protocolul final. Partea inițială constă într-o invocatio (verbalisl symbolica) și o secvență de intitulatio (prezentarea emitentului). Contextul este format din „notificație” și „expoziție” (în care sunt semnalate și prezentate clauzele), din două componente facultative („dispoziția” care stipulează intrarea proprietății în posesia unei rude și „clauza prohibitivă"), „sancțiunea” (blestemul) și „coroborația” (introducerea martorilor și a scribului ${ }^{29}$. În protocolul final sunt indicate elementele topografice și

22. Rudolf Dekker Introduction in Egodocuments and History. Autobiographical Writing in its Social Context since the Middle Ages, edited by Rudolf Dekker, Hilversum, Verloren Publishers, 2002.

23. Vezi capitolul V, Autobiografia : spovedanie sau justificare?, în Aaron J. Hurjewitsch, Individul in Evul Mediu european, trad. de Hans Neumann, Iași, Polirom, 2004, p. 119-166.

24. André Vauchez, Spiritualitatea Evului Mediu Occidental secolele VIII-XII, trad. de Doina Marian și Daniel Barbu, București, Editura Meridiane, 1994, p. 19.

25. Jean Delumeau, Frica in Occident (secolele XIV-XVIII) : o cetate asediată, vol. 1, trad. de Modest Morariu, București, Editura Meridiane, 1986, p. 49.

26. Philippe Ariès, Omul în fața morții, vol. I (Vremea gisanților), trad. de Andrei Niculescu, București, Ed. Meridiane, 1996, p. 20-23.

27. „Scena înglobantă corespunde sensului pe care îl dăm în mod normal «tipului de discurs»" (Ibidem, p. 222).

28. Gabriela Stoica, op. cit., p. 475.

29. Ibidem, p. 
cronologice care formează fundalul redactării testamentului.

A treia dimensiune a scenei de enunțare, scenografia ${ }^{30}$, este cea în care cuvântul se teatralizează, particularizând un anumit discurs față de genul și tipul în care este încadrat. Având în vedere acest aspect, propunem în continuare o analiză succintă a celor 2 diate și a scrisorii testamentare întocmite de Maria Cantemir în anii 1725 și 1757. Privind atent la discrepanțele rezultate în urma procesului de scriere și rescriere, suntem de părere că discursul acestui „epilog pregătitor de moarte” reprezintă o regie testamentară, a cărui scenografie poate fi considerată cea „a reconfigurării ${ }^{31}$ unei identități nobile”.

Prima diată, realizată de Maria Cantemir la vârsta de 25 de ani, se caracterizează prin convenționalitate discursivă și schematism. Aceasta începe cu o invocație scurtă și un preambul standard din care reținem formularea care indică faptul că testatoarea se erijează în responsabilitatea de locutor: „în numele fraților și al slugilor pe care le las în urmă, mă socotesc datornică să fac cunoscute" ${ }^{\prime 2}$. Acest testament are în centrul său o clauză laică, lămurirea valorii unor bijuterii lăsate de Dimitrie Cantemir fiicelor sale, ce trebuie îndeplinită de trei frați ai prințesei, Constantin și sora sa vitregă nefiind menționați printre executori.

În comparație cu primul, cel de-al doilea testament al „cneajnei” Cantemir (8 august 1757) surprinde prin amploarea sa discursivă. Fiind o diată tip commendatio (către generalul-feldmareșal Trubețkoi și Serghei Cantemir), documentul conține diferite directive, cele nouă clauze îmbinând cereri pioase și laice. Aspectul insolit al acestei diate constă în faptul că semnătura testatoarei nu se găsește, în mod convețional, doar la finalul documentului. Aceasta ia forma unor inserții ale unui ethos care nu se construiește în interiorul discursului, ci care, la nivel grafic, ia chipul unor „interpolări” care formează planuri secante cu strategiile

30. Elementul original care diferențiază discursul în sistemul generic în care se încadrează: „scena pe care cititorul își vede acordat un loc, este o scenă narativă construită de text”, scenografia teatralizează în scris, deci consemnează în memorie și „pune în scenă”, cuvântul ca produs și sursă a celorlalte scene (Ibidem, p. 223-224).

31. Utilizăm termenul "figură” în toate sensurile sale etimologice: fingere, figulus, fictor și effigies (a făuri un „model plastic”, roata olarului, artistul plastic, efigia ca formă de reprezentare). Vezi Erich Auerbach, Scenes from the Drama of European Literature în Wlad Godzich, Jochen Schulte-Sasse (ed.), Theory and History of Literature, vol. 9, Minnesota, University of Minnesota Press, 1984, p. 11-76.

32. Trad. n. - D.M. (Lilia Zabolotnaia, The First Testament of Maria Catemir, from 1725, p. 53). 
de recuperare ale ethos-ului prediscursiv (statutul nobil real). Imaginea locutorului, privit din interiorul discursului, se face vizibilă, în efigie, prin intermediul pathos-ului. Astfel, enumerarea și detaliile cantitative cu care se schițează recuzita sărindarelor și a ceremonialului funerar trec de la umilință („și păcătosul meu trup să fie înhumat fără de nici o ceremonie la moșia mea din satul Marino de lângă Moscova, unde eu doresc să fie ridicată o mănăstire de maici”) până la o acribie care emfatizează discursiv dorința de a asigura memoria liturgică („Preotului acelei biserici să-i fie date douăzeci de ruble, iar țârcovnicilor aceleiași biserici să li se dea douăzeci de ruble, dat fiind faptul că ei trebuie timp de șase săptămâni să citească zi și noapte Psaltirea patruzeci de zile în douăzeci de biserici - de către preot și citeți - câte două ruble și jumătate, pentru tămâie, lumânări, vin bisericesc, pentru colivă - câte o rublă și jumătate de fiecare biserică, iar pentru a pomeni în doăzeci de biserici - câte zece ruble de ficare biserică”). Aceeași grijă de a-și conserva memoria post-mortem trădează, în cazul scrisorii testamentare atașate celei de a doua diate, încercarea de a recupera și de a eterniza o identitate nobilă: „Deasupra corpului meu să fie zidită o capelă rotundă de piatră cu dimensiunea interioară de cinci arșini. Pe cercul acelei capele, pe exterior să fie făcute stemele noastre, să fie acoperită cu lespezi albe, de instalat deasupra capelei o cruce de cupru poleită cu aur [...]. Sicriul să fie pus în centrul capelei și să fie acoperit cu o cuvertură de atlaz de culoarea zmeurii cusut și împletit cu fir de aur, iar crucea pusă, făcută la ceapraz din aur lat, iar acoperământul pus în fiecare zi să fie din postav negru cu dantelă de mătase". În acest sens, este vizibil că recuzitei funerare i se acordă o atenție mai mare, fapt care, la nivelul discursului, se reflectă prin descrierea bazată pe termeni aflați în serii ierarhice tip „temă-subtemă”33 (,lespezi”, „cruce”, „cupru”„aur”, „cuvertură”- „acoperământ”, ,atlaz”, „postav”, „dantelă”, „mătase”). Aceștia sunt utilizați gradual, distingând în cazul capelei (obiect ex voto), un registru exterior (arhitectural), de unul interior, ce se construiește în jurul sicriului. Tendința de a recupera prestigiul princiar este decelată prin gestul prințesei Cantemir de a-i lăsa împărătesei Elizaveta Petrovna (17411761) un colier de perle („perla cea mare”) numai „în caz dacă va costa nu puțin, [...], iar dacă va fi evaluată la un preț nu prea mare apoi să fie dăruită executorului meu de încredere”. Nu în ultimul rând, fiind vorba despre o epistolă, deicticele utilizate pot fi privite ca resorturi de impunere

33. Dominique Maingueneau, Lingvistică pentru textul literar, trad. de Ioana-Crina Coroi, Nicoleta Moroșan, Iași, Institutul European, 2008, p. 148-150. 
şi re-punere în discurs a identităţii princiare. Pe de-o parte, formula de adresare către interlocutor (Serghei Dimitrovici) constă în alăturarea dintre un deictic social ce implică distanță (,stăpâne”) și unul personal, marcat afectiv („frățioare”), fapt care trasează de la început un cadru discursiv formal, în interiorul căruia persuasiunea apelează și la afecte filiale. Pe de altă parte, locutorul se plasează în două poziții discursive simetrice faţă de cele ale interlocutorului, testatoarea semnându-se in hora mortis „soră prințesă Maria Cantemirova”.

În concluzie, privite fie ca discursuri ancorate social, fie ca documente autobiografice cu valență de justificare spirituală, testamentele prezintă funcția de preparatio mortis, acestea devenind un spațiu în care bunurile pământești (temporalia) se racordează la cele cerești (aeterna). În ceea ce privește diatele Mariei Cantemir, acestea se îndepărtează, în mare măsură, de modelele testamentare din secolul al XVIII-lea și, în mod atipic, oferă o importanță desăvârșită clauzelor pioase. Privite ca discursuri literare, dincolo de scena înglobantă și cea generică, aceste testamente se particularizează prin scenografia reconfigurării imaginii nobile. Astfel, acestea proiectează o oglindă în care testatoarea, pusă în fața morții, își reface pentru ultima oară imaginea princiară (ethos-ul prediscursiv), pornind de la vocea surorii până la semnătura „cneajnei” și ecranizarea unei memorii post-mortem pe care "prezentul discursului” o poate garanta numai prin regizarea și punerea în scenă a ceremonialului funerar. 


\section{Bibliografie \\ Bibliografie primară}

Ms. rom. BAR 2120.

Eșanu, Andrei, Eșanu, Valentina, Testamentul prințesei Maria Cantemir în „Revista de Istorie a Moldovei”, nr. 1 (105), 2016, p. 102-135.

Zabolotnaia, Lilia, The First Testament of Maria Catemir, from 1725 în „Tyragetia”, vol. XI [XXVI], nr. 2, 2017, p. 51-60.

\section{Bibliografie secundară}

Aries, Philippe, Omul in fața morții, vol. I (Vremea gisanților), Traducere de Andrei Niculescu, București, Editura Meridiane, 1996.

Auerbach, Erich, Scenes from the Drama of European Literature in Wlad Godzich, Jochen Schulte-Sasse (ed.), Theory and History of Literature, vol. 9, Minnesota, University of Minnesota Press, 1984.

Barbu, Violeta, De bono coniugali: o istorie a familiei din Țara Românească in secolul XVII, București, Editura Meridiane, 2003.

Barthes, Roland, Romanul scriiturii, antologie și traducere de Adriana Babeți și Delia Șepețean Vasiliu, București, Editura Univers, 1987.

Bianu, Ion (ed.), Bibliografia Românească Veche, vol. I., București, Editura Stabilimentul Grafic J.V. SOCEC, 1903.

Chivu, Gh., Limba română de la primele texte până la sfârșitul veacului al XVIII-lea. Variantele stilistice, București, Editura Univers Enciclopedic, 2000.

Dekker, Rudolf, Introduction in Egodocuments and History. Autobiographical Writing in its Social Context since the Middle Ages, edited by Rudolf Dekker, Hilversum, Verloren Publishers, 2002.

Delumeau, Jean, Frica in Occident (secolele XIV-XVIII) : o cetate asediată, vol. 1, Traducere de Modest Morariu, București, Editura Meridiane, 1986.

Dobre-Bogdan, Cristina, Imago mortis în cultura românească veche (secolele XVII-XIX), București, Editura Universității din București, 2002.

Hurjewitsch, Aaron J., Individul in Evul Mediu european, Traducere de Hans Neumann, Iași, Editura Polirom, 2004.

Iancu, Andreea-Roxana, Iertarea în actul de ultimă voință: între discurs și practică socială (Țara Românească, jumătatea secolului al XVIIIlea - inceputul secolului al XIX-lea) în Constanța Vintilă-Ghițulescu și Mária Pakucs Willcocks (coord.), Spectacolul public intre tradiție și modernitate: sărbători, ceremonialuri, pelerinaje și suplicii, București, Editura Institutul Cultural Român, 2007, p. 265-300. 
Ivireanul, Antim, Opere, ed. de Gabriel Ștrempel, București, Editura Minerva, 1972.

Le Goff, Jacques, Civilizația Occidentului Medieval, Traducere de Maria Holban, București, Editura Științifică, 1970.

Le Goff, Jacques, Imaginarul medieval, Traducere de Marina Rădulescu, București, Editura Meridiane, 1991.

Lemny, Ștefan, Sensibilitatea și istorie în secolul XVIII românesc, ed. a II-a, Iași, Editura Polirom, 2017.

Maingueneau, Dominique, Discursul literar: paratopie și scenă de enunțare, Traducere de Nicoleta Loredana Moroșan, Iași, Editura Institutul European, 2007.

Maingueneau, Dominique, Lingvistică pentru textul literar, Traducere de Ioana-Crina Coroi, Nicoleta Moroșan, Iași, Editura Institutul European, 2008.

Mareș, Al., Introducere în Gh. Chivu et alii, Documente și însemnări românești din secolul al XVI-lea, București, Editura Academiei Române, 1979.

Mazilu, Dan Horia, Văduvele sau despre istorie la feminin, Iași, Editura Polirom, 2008.

Mihai, Nicolae, Ultimul gest. Atitudini și reprezentări faţă de moarte în sursele testamentare din Oltenia (1700-1860) în Radu Mârza, Laura Stanciu (coord.), Cum scriem istoria? Apelul la ştiinţe şi dezvoltările metodologice contemporane, Alba -Iulia, Editura Aeternitas, 2003.

Muşat, Carmen, Frumoasa necunoscută : literatura și paradoxurile teoriei, Iași, Editura Polirom, 2017.

Stoica, Gabriela, CONSTANTINESCU, Mihaela, BĂRBULESCU, Oana Uță, Observații asupra dispozițiilor testamentare din secolul al XVIIlea, în Gabriela Pană Dindelegan (coord.), Limba română: dinamica limbii române, dinamica interpretării, București, Editura Universității din București, 2008.

Ștrempel, Gabriel, Catalogul manuscriselor românești, vol. 1-4, București, Editura Științifică și Enciclopedică, 1978, 1983, 1987, 1992.

Vauchez, André, Spiritualitatea Evului Mediu Occidental secolele VIIIXII, Traducere de Doina Marian și Daniel Barbu, București, Editura Meridiane, 1994.

VINTILĂ-GHIȚULESCU, Constanța, În șalvari și cu ișlic: biserică, sexualitate, căsătorie și divorț în Țara Românească a secolului al XVIII-lea, București, Editura Humanitas, 2011. 


\section{ANEXĂ}

Cum să scrie diiată la ceasu $l$ morții

De vreame ce au înșelat șarpele ce $l$ rău și amăgitor ${ }^{34}$, vicleanu $l$ diiavol, dintru început pre o $m$ și l-au dus la voia lui cu acest cuvân $t$ amăgitoriu, trăgându- $l$ dintru înălțimea vieții în prăpastiia cumpliciunii, $\mathrm{ad}<\mathrm{ică}>$ spre cea înfricoșată și amară moarte, și așa s-au osăndit ticălosul să fie $<$ a $>$ măgitoriu de acolo de unde era neamăgitoriu, pentru aceasta s-au dat și s-au hotărâ<t> această moarte la tot neamul omenesc ca o moștenire și nu iaste cu putință ca să scape de dânsa niminea.

Și, de vreame ce eu (cutare) $)^{35}$, ca unul din oameni, cunoscându- $m$ sfârșitul vieții meale și încă până îm sânt în fire și în preceperea mea am socotit să fac diiată de toate câte află mișcătoare și nemișcătoare, și dară încă rânduiesc să să dea la îngrop<ă>jeanea (atâta) ${ }^{36}$, a doua ${ }^{37}$ să să dea la sărindar (atât), a treia, copiilor miei, soției meale (atât), a patra, la lipsiț (atât). Acestea de bunăvoința inimii meale le-am rânduit, ci dar cine din rudeniile meale sau din străini a $r$ îndrăzni ca să strămute acestea ce am așezat eu întâi, să aibă pre Sfânta Troiță grabnic răsplătire, așijderea pre toț sfinții păr $<$ inți> pârâş în zio<a $>$ cea înfric < o >șată a Judecăț, partea lui să fie cu Viliar și să fie gemând și tremurând pre pământ întru viiața lui / căloșaște, cu suspin să să îmbăluiască și cu toată pornirea iuților doriri să fie împovărat, soarta lui să fie cu Iuda ${ }^{38}$. Amin.

\section{Scris: amăgitori.}

35. Parantezele îi aparțin copistului.

36. Parantezele îi aparțin copistului.

37. Scris: a do(ÿ).

38. Scris: Iiuda. 